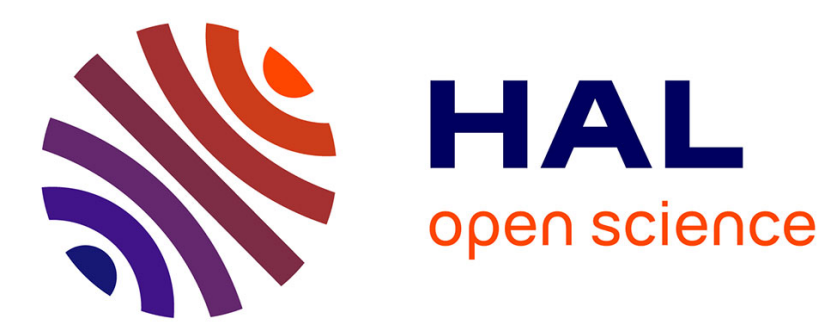

\title{
Are Figs Always Keystone Resources for Tropical Frugivorous Vertebrates? A Test in Gabon Annie Gautier-Hion, Georges Michaloud
}

\section{To cite this version:}

Annie Gautier-Hion, Georges Michaloud. Are Figs Always Keystone Resources for Tropical Frugivorous Vertebrates? A Test in Gabon. Ecology, 1989, 70 (6), pp.1826-1833. 10.2307/1938115 . hal-01369757

\section{HAL Id: hal-01369757 https://hal-univ-rennes1.archives-ouvertes.fr/hal-01369757}

Submitted on 21 Sep 2016

HAL is a multi-disciplinary open access archive for the deposit and dissemination of scientific research documents, whether they are published or not. The documents may come from teaching and research institutions in France or abroad, or from public or private research centers.
L'archive ouverte pluridisciplinaire HAL, est destinée au dépôt et à la diffusion de documents scientifiques de niveau recherche, publiés ou non, émanant des établissements d'enseignement et de recherche français ou étrangers, des laboratoires publics ou privés. 


\title{
ARE FIGS ALWAYS KEYSTONE RESOURCES FOR TROPICAL FRUGIVOROUS VERTEBRATES? A TEST IN GABON ${ }^{1}$
}

\author{
ANNIE GAUTIER-HION \\ Station Biologique de Paimpont, CNRS UA 373, 35380 Plélan-le-Grand, France \\ AND \\ Georges Michaloud \\ Institut de Botanique, CNRS UA 327, Rue A. Broussonet, 64000 Montpellier, France
}

\begin{abstract}
This paper evaluates the suggestion of Terborgh (1986) that figs constitute "keystone plant resources" for frugivorous mammals and birds in African rain forests as they appear to do in South America and Asia. From studies of the diets of monkeys and other mammals and birds in Gabon, we show that figs are infrequently eaten by most species, and are always eaten in small amounts. Figs in Gabon occur at very low densities and have unpredictable fruiting patterns and relatively low crown production. Thus, fig fruits are not staple foods and cannot sustain most populations of frugivorous species during periods of low fruit availability. In Gabon, monkeys and large birds depend on the fruit of two species of Myristicaceae and of one species of Annonaceae. These regularly bear ripe fruit during the lean period and are abundantly consumed. Figs occur in such distant patches that they are mainly fed on by wide-ranging animals such as large frugivorous bats.
\end{abstract}

Key words: Annonaceae; figs; frugivorous vertebrates; Gabon; keystone resources; Myristicaceae; rain forest monkeys.

\section{INTRODUCTION}

Leighton and Leighton (1983) showed the importance of figs in a Bornean rain forest by identifying 30 species important to diurnal birds and monkeys. They stated that "the reproductive biology of figs makes them uniquely suited to play roles as keystone mutualists for many vertebrates."

In a recent paper, Terborgh (1986) identified several plants that play a "key role" in the nutrition of frugivorous vertebrates during the period of fruit scarcity in the Manu tropical rain forest (Peru). Three species of palm nut and three figs were the most important of these resources. All were characterized by: a low interannual variation in fruit production, and/or by a regular timing of their fruiting period, and by a high rate of consumption by frugivorous animals. According to Terborgh, both palm nuts and figs are important for birds and mammals throughout the neotropics, while figs might play a prime role in Southeastern Asia and Africa. In the present paper, we evaluate Terborgh's suggestion for frugivorous mammals and large birds living in northeastern Gabon.

\section{SCOPE OF THE STUDY}

To determine the existence and identity of key resources, we focus on the main foods consumed during the lean season, compared to those taken during the rest of the year. This comparison is based mainly on

\footnotetext{
${ }^{1}$ Manuscript received 25 July 1988; revised and accepted 3 January 1989.
}

cercopithecines, but additional evidence from other taxa is also considered. We then closely examine the case of figs and their use as foods. We further stress the features (density, patterns of distribution, fruiting phenology, and fruit production) that enable plant species to play a key role in sustaining frugivore populations. Finally, we discuss the applicability of our results to other tropical forests.

\section{Study Site And Animal Community}

All the observations reported below come from the tropical rain forest around Makokou, Gabon $\left(0^{\circ} 04^{\prime} \mathrm{N}\right.$, $\sim 500 \mathrm{~m}$ altitude), particularly the M'passa plateau. The climate of the area is characterized by an annual rainfall (10-yr mean) of $1621 \mathrm{~mm}$, and by the following alternation of seasons: a minor dry season (December through February), a minor rainy season (March through May), a major dry season (June through August) and a major rainy season (September through November). During the major dry season, rains are almost absent.

The extent of frugivory in mammals and large birds of the Makokou Forest is well established (GautierHion et al. 1980, Emmons et al. 1983, Gautier-Hion et al. 1985a, Brosset and Erard 1986). Detailed information has been published on the diets of forest rats (Duplantier 1982), squirrels (Emmons 1980), ruminants (Dubost 1984, Feer 1988) and monkeys (Gautier-Hion 1971, 1977, 1980, Quris 1975, Gautier-Hion and Gautier 1978, Gautier-Hion et al. 1981, Sourd 1983). Overall, fruit and seeds make up $\sim 78 \%$ on av- 
erage of the diet of $85 \%$ of the 66 mammalian primary consumers.

\section{Plant Community and Fruiting Patterns}

Fruiting in the Makokou Forest is seasonal (Emmons 1980, Gautier-Hion 1980, Gautier-Hion et al. 1981, 1985b). Despite interannual variations (in a 5 -yr sampling), the mean number of fruiting species and fruiting individuals is greatest from October to February and lowest from June to August, i.e., during the major dry season, which represents the lean period for frugivorous vertebrates.

\section{Methods of ANALYSIS}

The annual diets of frugivores were analyzed by two methods: (1) the study of stomach contents taken from animals shot by hunters (Gautier-Hion 1980); and (2) the percentage of a given fruit species relative to all fruit consumption events (one feeding event being recorded for each 15 -min interval, over the daily activity cycle, Sourd and Gautier-Hion 1986). Fruit availability was estimated by: (1) the mean number of fruiting individuals found on a $6-\mathrm{km}$ trail visited twice a month over a 1-yr period (Gautier-Hion et al. 1985b); and (2) the mean number of fruiting individuals per hectare encountered by visiting six different 1-ha plots weekly over one main dry season and the subsequent main rainy season. The number of fruits per tree was counted on felled trees (P. Heckestweiler, personal communication) and the fruit biomass calculated from the mean fruit mass. Plant species densities were obtained from mapping individuals over a surface area ranging from 7 to 100 ha depending on the species (for figs, see Michaloud and Michaloud-Pelletier 1987, Michaloud 1988).

\section{RESULTS}

\section{The staple foods for monkeys}

Analyses of 270 stomach contents and feeding observations were conducted on five species of guenons and two species of mangabeys. It has previously been shown (Gautier-Hion 1971, 1977, 1980, Quris 1975, Gautier-Hion and Gautier 1978, Gautier-Hion et al. 1981, Sourd 1983) that a large proportion of the monkeys' diet is made up of a small number of fruit species. This includes the fruits of Cissus dinklagei (Vitaceae), Polyalthia suaveolens (Annonaceae), and some members of the Apocynaceae and the Myristicaceae.

Staple foods outside the major dry season. - 1. Cissus dinklagei. - Fruiting of this liana is bimodal, with maxima occurring during the rainy season (Fig. $1 \mathrm{Aa}, \mathrm{Ab}$ ). Fruits are succulent drupes that make up the major food of at least three monkey species. Fruit remains occurred in $62 \%$ of stomachs of Cercopithecus pogonias, $52 \%$ of $C$. cephus, and $38 \%$ of $C$. nictitans ( $n=$ 214) over the year. Consumption lasted over $11 \mathrm{mo}$, and during four of the rainy months, $>50 \%$ of all stomachs contained large amounts of Cissus seeds (Fig. 1Ac). During the major dry season, Cissus seeds were found in $<10 \%$ of the stomachs. Similarly, the monthly percentage of sampling of Cissus fruit by a C. cephus troop had a yearly mean of $12.5 \%$, with a minimum (0-4\%) during the major dry season and a maximum (35\%) during rainy months (Fig. 1Ad).

2. Apocynaceae. - Fruit of five apocynaceous lianas are commonly included in the monkeys' diets, the most frequent being those of Dictyophleba stipulosa, Cylindropsis parvifolia, and Landolphia sp. The overall fruiting pattern of these species is centered around the minor dry season (Fig. 1Ba). Fruits are large, brightly coloured polyspermous berries, covered by a thick, inedible husk enclosing a number of seeds embedded in a succulent pulp. Seeds occurred in an average of $15 \%$ of guenons' stomachs over the whole year. They reached $20 \%$ during a 4-mo period. No apocynaceous remains were found in stomachs during the major dry season (Fig. 1Bc). Similarly, these plants made up $\sim 13 \%$ of the annual feeding records of a C. cephus troop and reached monthly averages around $20 \%$ from October to April (Fig. 1Bd).

In summary, together with fruits of Cissus, those of the Apocynaceae were present in $>50 \%$ of stomachs and averaged $40 \%$ of the food items sampled by monkeys outside the major dry season.

Staple foods during the major dry season.-During the major dry season, fruit availability decreased and staple foods were no longer available. The diets of the monkeys changed significantly. A lower proportion of fruits was eaten and fewer species were sampled per day, while the consumption of insects and/or leaves increased (Gautier-Hion 1980). During this period, three fruit species were eaten most commonly: Polyalthia suaveolens and Coelocaryon preussii, followed at a lower rate by Pycnanthus angolensis.

1. Polyalthia suaveolens. -This species shows two fruiting peaks, which occurred during the two dry seasons (Fig. $1 \mathrm{Ca}, \mathrm{Cb}$ ). The fruits are berries, which were rarely identified in monkeys' stomachs, because only the pulp is usually swallowed. Direct observations, however, showed that these fruits constituted $>25 \%$ of the monthly feeding records of C. cephus in June and July (Fig. 1Cd), and 15-20\% for C. nictitans and C. pogonias.

2. Coelocaryon preussii and Pycnanthus angolensis. - These two species of Myristicaceae bear dehiscent monospermous drupes with arils surrounding the seeds. Fruits ripen during the major dry season: Coelocaryon is in fruit mainly from June to August, while the fruiting period of Pycnanthus extends into the following rainy season (Fig. 1Da, Db). In the main dry season, arils with or without seeds were present in $80,75,69$, and $45 \%$ of the stomachs of Cercocebus albigena, Cercopithecus pogonias, $C$. nictitans, and $C$. cephus, respectively. In August, $100 \%$ of the stomachs analyzed 
a

b
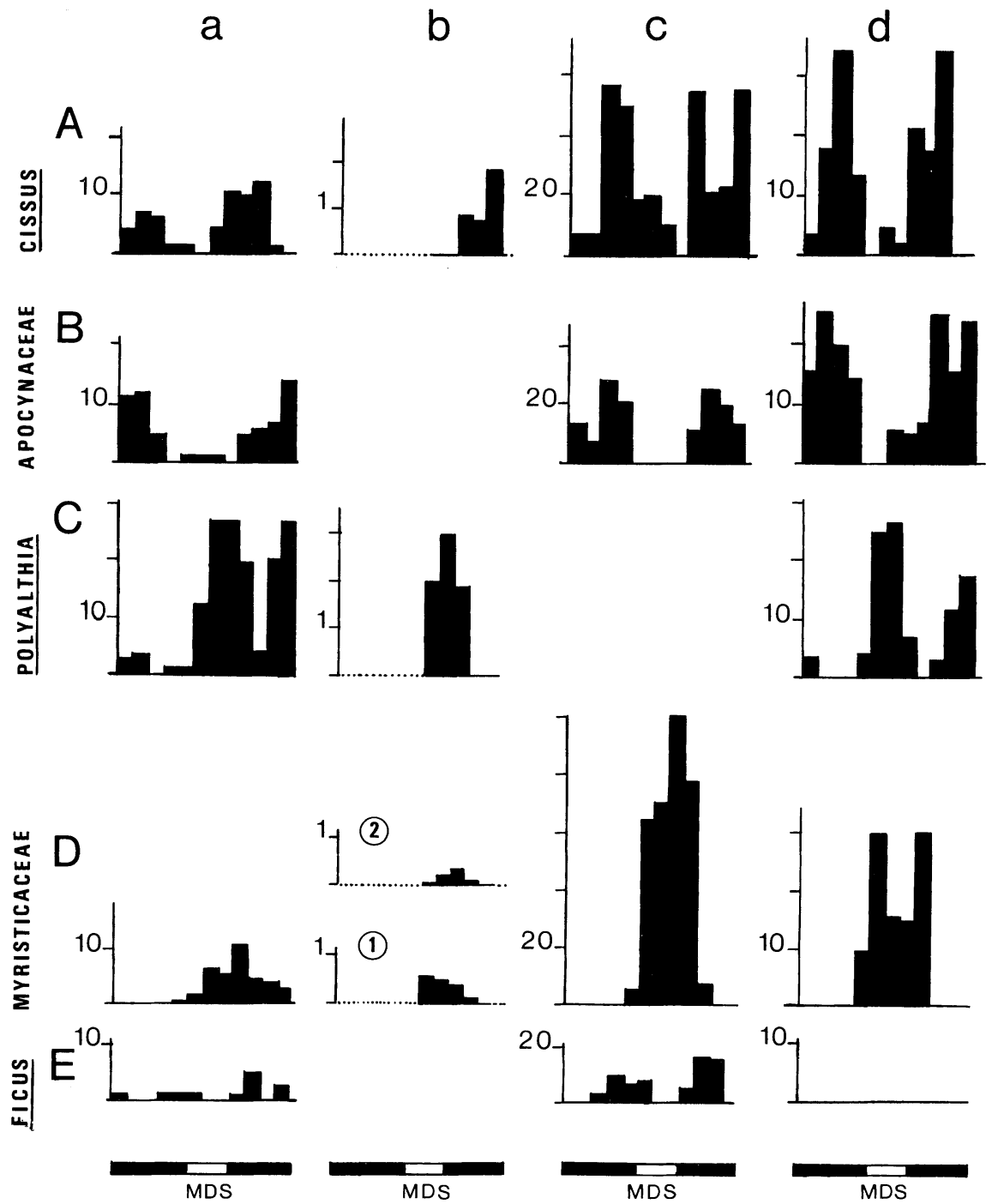

FIG. 1. Fruit availability (ripe fruit) and fruit consumption over the annual cycle from January through December. Left to right: (a) mean number of fruiting individuals found per $100 \mathrm{~m}$; (b) mean number of fruiting trees per hectare; (c) percentage of guenon stomachs including fruit remains; (d) percentage of feeding records by a C. cephus troop. Top to bottom: (A) Cissus dinklagei; (B) Apocynaceae (Dictyophleba stipulosa, Cylindropsis parvifolia, Landolphia sp.); (C) Polyalthia suaveolens; (D) Myristicaceae: Coelocaryon preussii (1), Pycnanthus angolensis (2); (E) Ficus spp. MDS = major dry season.

contained one or both species (Fig. 1Dc). Both species made up $20 \%$ per month, on average, of the feeding records of $C$. cephus during the main dry season (Fig. $1 \mathrm{Dd}$ ) and up to $30 \%$ for $C$. pogonias.

To sum up, berries of Polyalthia and arils of Coelocaryon and Pycnanthus accounted for $\sim 50 \%$ of the food items sampled by monkeys from June through August and constituted major resources during the lean period.

\section{Polyalthia suaveolens and the Myristicaceae in the diets of other mammals and large birds}

Among 32 species of frugivorous mammals and large birds for which lists of consumed food items are avail- able, $65 \%$ are known to eat Coelocaryon and/or Pycnanthus fruits. These included: 4 out of 7 frugivorous small terrestrial rats (Duplantier 1982), the 2 large terrestrial rodents, 4 out of 8 squirrels (L. Emmons 1980 and personal communication), 6 out of 7 ruminants (Dubost 1984), all 4 hornbills and 1 out of 3 turacos (C. Erard, personal communication). A similarly large assemblage has been observed to eat Polyalthia fruits (6 small rats and 2 large rodents, 2 squirrels, 7 ruminants, 3 turacos, and at least 3 hornbills). In addition, both Polyalthia fruit and arils of Myristicaceae were eaten by blackbirds, bulbuls, and some other small birds (Brosset and Erard 1986; C. Erard, personal communication). 
The amount of these food species in the diets of these animals has not been estimated in all cases. However, Polyalthia was noted as one of the species most frequently consumed by Cephalophus dorsalis and C. callipygus (Feer 1988). Similarly, its fruits were present in large amounts in $64 \%$ of the 19 turaco and hornbill gizzards analyzed by J-P. Decoux and C. Erard (personal communication) from June to July. At this period, fruiting trees in the Myristicaceae were the most important feeding places for hornbills, blackbirds, and other birds, as they were for cercopithecines. Agonistic interactions among species were observed: monkeys displaced hornbills and the latter displaced smaller birds. Nocturnal and diurnal terrestrial mammals were also observed there. Therefore, Myristicaceae and Polyalthia fruits likely play a key role for a large community of mammals and birds.

\section{Figs in the diets of mammals and large birds}

For all fig species combined (namely 20 hemi-epiphytic species, Michaloud and Michaloud-Pelletier 1987), figs were so rare along the $6-\mathrm{km}$ trail censused that no seasonal fruiting pattern could be detected (Fig. $1 \mathrm{Ea})$.

Fig use by monkeys. - Figs are included in the list of food species of all mainland forest-dwelling monkeys studied (Gautier-Hion 1977, 1980). However, fig seeds were found in $<8 \%$ of the stomachs of Cercocebus albigena, Cercopithecus nictitans, $C$. pogonias, and $C$. cephus, and were not included in their diets in July and August (Fig. 1Ec). Further, the number of figs eaten was always very low. Direct observations showed that monkeys did not actively search for fig trees, but fed on them opportunistically. The best evidence came from the fact that figs were not included in the fruit species sampled by a $C$. cephus troop followed during five consecutive months covering the major dry season and the subsequent rainy season (Gautier-Hion et al. 1981). Figs were not included in the diet of a neighboring troop followed over $1 \mathrm{yr}$ (Sourd and GautierHion 1986, Fig. 1Ed).

Although fig trees are more numerous in riparian than in mainland forest (46.5 and 1.5 individuals/ha, respectively), the importance of figs is not different for the three monkey species living in riparian forests. Figs were observed taken occasionally by Miopithecus talapoin in only 5 mo (all out of the main dry season); only 1 of 19 stomachs analyzed included fig seeds (Gautier-Hion 1971). Fig seeds occurred in 2 of 9 stomachs of Cercopithecus neglectus examined, and two direct observations of fig consumption were made during a 4-mo study (Gautier-Hion and Gautier 1978). Infrequent consumption of figs by Cercocebus galeritus was also reported by Quris (1975).

Fig use by other mammals and birds. -Figs were noted in the diet of only two squirrel species (Emmons 1980) and one ruminant (Dubost 1984). When examining 19 hornbill and turaco gizzards in June and
July, C. Erard and J-P. Decoux (personal communication) found fig seeds in only one Tauraco macrorhyncus gizzard. Like monkeys, these large, canopy birds are opportunistic fig-eaters which do not actively monitor fig trees (C. Erard, personal communication). Among the smaller frugivorous birds, Brosset and Erard (1986) observed that figs were eaten by 6 of 15 species of Pycnonotidae, by 2 of 4 Sturnidae, and 3 of 8 species of Columbidae. However, these authors mentioned figs as important resources for only one columbid and one pycnonotid.

Six frugivorous bats occur in Makokou forest. Bradbury $(1977,1981)$ found that figs constituted a large amount of the diets of the two large species: Hypsignathus monstruosus and Epomops franquetti. Eightyeight percent of the 133 oral swabs and fecal samples of $H$. monstruosus analyzed from May to October contained seeds of Ficus.

To conclude, figs cannot be considered as a staple food for monkeys at Makokou, nor as a major resource when fruit availability is low. Further, they do not appear to be important for large birds of the canopy, for most mammals, or for many birds of smaller size. In fact, they appear to be major food only for bats.

\section{Key resources and foraging}

Table 1 summarizes some characteristics of the biology of the three species identified as major plant foods in the major dry season. Polyalthia ranks sixth among the most abundant species on M'passa plateau (Caballé 1986), while Coelocaryon (ranked 20th) and Pycnanthus occur at lower densities $(17.57,1.12$, and 0.44 individuals/ha, respectively, Table 1). In all three species, fruiting peaks occur in the main dry season, without significant interannual variations and with a high intraspecific synchrony (Gautier-Hion et al. 1985b). In July, a mean of 2.22 Polyalthia, 0.65 Coelocaryon, and 0.04 Pycnanthus trees/ha were found simultaneously bearing fruit. In August, these figures reached 2.92, 0.66, and 0.08 trees/ha (Table 1). Fruit crops are relatively large. The average biomass of fruit per individual plant for Polyalthia, Coelocaryon, and Pycnanthus are 14, 50, and $140 \mathrm{~kg}$, respectively, when the whole fruit mass is considered, or 7,3 , and $10 \mathrm{~kg}$, respectively, when only the pulp or arils are taken into account (Table 1). These arils are especially rich in lipids, and they also contain high levels of proteins (Sourd and Gautier-Hion 1986). Thus, these three plant species are well-distributed, highly predictable, abundant, and rich foods. They are particularly well suited to play a key role for frugivores during a season of fruit scarcity.

Ficus species display quite opposite characteristics. Species density is very low, ranging from 0.1 to a maximum of 0.32 individuals/ha on the M'passa plateau, with a mean overall density of 1.5 individuals/ha for all 20 species grouped (Michaloud and Michaloud-Pel- 
TABLE 1. Some features of the reproductive biology of three key resources for frugivores during the lean fruit period.

\begin{tabular}{|c|c|c|c|}
\hline & \multicolumn{3}{|c|}{ Species } \\
\hline & Polyalthia & Coelocaryon & Pycnanthus \\
\hline \multicolumn{4}{|c|}{ Density (no. individuals/ha) } \\
\hline $\begin{array}{l}\bar{X} \pm \text { SD } \\
\text { Range } \\
\text { Sample }\end{array}$ & $\begin{array}{c}17.57 \pm 7.46 \\
8-30 \\
7 \text { ha }\end{array}$ & $\begin{array}{c}1.12 \pm 1.36 \\
0-6 \\
25 \mathrm{ha}\end{array}$ & $\begin{array}{c}0.44 \pm 0.05 \\
0-3 \\
25 \mathrm{ha}\end{array}$ \\
\hline \multicolumn{4}{|l|}{ Fruiting timing } \\
\hline $\begin{array}{l}\text { Peaks } \\
\text { Interannual variations } \\
\text { Intraspecific synchrony }\end{array}$ & $\begin{array}{c}\text { two dry seasons } \\
\text { low } \\
\text { high }\end{array}$ & $\begin{array}{c}\text { main dry season } \\
\text { low } \\
\text { high }\end{array}$ & $\begin{array}{c}\text { main dry season } \\
\text { low } \\
\text { high }\end{array}$ \\
\hline \multicolumn{4}{|l|}{$\begin{array}{l}\text { No. fruiting trees/ha: } \\
\text { July }\end{array}$} \\
\hline $\begin{array}{l}\overline{\bar{X}} \pm \mathrm{sD} \\
\text { Range } \\
\text { Sample }\end{array}$ & $\begin{array}{c}2.22 \pm 1.91 \\
0-5 \\
23 \mathrm{ha}\end{array}$ & $\begin{array}{c}0.65 \pm 0.77 \\
0-3 \\
23 \mathrm{ha}\end{array}$ & $\begin{array}{c}0.043 \pm 0.21 \\
0-1 \\
23 \mathrm{ha}\end{array}$ \\
\hline \multicolumn{4}{|l|}{ August } \\
\hline $\begin{array}{l}\bar{X} \pm \text { SD } \\
\text { Range } \\
\text { Sample }\end{array}$ & $\begin{array}{c}2.92 \pm 1.91 \\
0-7 \\
24 \text { ha }\end{array}$ & $\begin{array}{c}0.66 \pm 0.96 \\
0-3 \\
24 \text { ha }\end{array}$ & $\begin{array}{c}0.083 \pm 0.28 \\
0-2 \\
24 \text { ha }\end{array}$ \\
\hline \multicolumn{4}{|l|}{ No. of fruits/tree* } \\
\hline $\begin{array}{l}\bar{X} \pm \mathrm{sD} \\
\text { Sample }\end{array}$ & $\begin{array}{c}5790 \pm 5133 \\
7 \text { trees }\end{array}$ & $\begin{array}{l}3045 \pm 2680 \\
4 \text { trees }\end{array}$ & $\begin{array}{c}8443 \pm 3779 \\
4 \text { trees }\end{array}$ \\
\hline \multicolumn{4}{|c|}{ Fruit biomass (kg/individual) } \\
\hline $\begin{array}{l}\text { Whole fruit } \\
\text { Pulp or aril }\end{array}$ & $\begin{array}{c}14 \\
7.2\end{array}$ & $\begin{array}{r}55 \\
3\end{array}$ & $\begin{array}{r}140 \\
10\end{array}$ \\
\hline
\end{tabular}

* P. Heckestweiler, personal communication.

letier 1987). This low density is accompanied by a lack of fruiting peaks.

We monitored 67 trees in 1977-1978 and 150 in 1980. For four sampling days (in July, August, October, and February), the percentage of trees bearing fruit varied from $1.5 \%$ to a maximum of $9 \%$. When only ripe fruits were considered, this percentage varied from 0 to $3.3 \%$. In both cases, the minimum was observed during the main dry season (namely $1.5 \%$ in July and $4.2 \%$ in August for the whole fruit, and $0 \%$ in July and $1.4 \%$ in August for ripe fruits).

Similarly, from May to October, Bradbury (1977) found a maximum of $7 \%$ of trees fruiting during any single month (35 trees over 19 ha). During his 1 st yr of observation, he observed only two fruiting trees in July, one in August, none in June, and no fruiting at all over the same 3 mo during the second year.

In addition to this interspecific asynchrony of fruiting, we found that fruiting among fig trees of any single species was highly asynchronous while fruiting within each tree was synchronous, the whole crop ripening in a short period of 5-10 d. Furthermore, the individual crop production was usually low (a few hundred to a few thousand fruits on a single tree) except for successful stranglers, which were able to give huge crops due to their ability to reach a larger crown development. Only 5 out of the 20 fig species (39 of the 150 trees) found at M'passa, Ficus burretiana, F. macrosperma, $F$. wildemaniana, $F$. cyathistipulö̈es, and $F$. elasticoïdes, have the ability to strangle. Only 7 out of these 39 individuals did strangle their hosts (C. Berg and G. Michaloud, unpublished manuscript) and only three of these were successful stranglers that gave huge crops ( $>10000$ fruits) at fruiting intervals ranging from 1 to $3 \mathrm{yr}$.

Figs are thus an unpredictable resource, always produced by a few trees that are widely scattered. The combined effects of low density, low individual production, and small number of simultaneously fruiting individuals make figs unsuitable to sustain populations of sedentary animals.

To illustrate the situation, we have plotted on Fig. 2 the Polyalthia, Coelocaryon, and Pycnanthus trees simultaneously bearing ripe fruits during two daily surveys covering 6 ha each, and the fruiting Ficus recorded among the 150 trees monitored in $1 \mathrm{~d}$ on 100 ha. It can be seen that randomly foraging animals, even those with small foraging ranges, can expect to encounter a significant number of Polyalthia, Coelocaryon, and even Pycnanthus fruiting trees on a given day. On the contrary, only wide-ranging animals could expect to visit a significant number of patches when relying on figs. Indeed, only nine trees bearing fruit including only five trees with ripe fruit occurred on 100 ha (Fig. 2).

\section{Discussion}

This study provides evidence that figs in the Makokou Forest are infrequently and opportunistically eaten in small amounts by frugivorous birds and mammals except for large bats. Reliance on such food patches 
requires that a species be able to forage very widely. This is obviously the case for $H$. monstruosus or $E$. franguetti, two bats that are able to visit quite distant figs in a single night (Bradbury 1981). The importance of wide-ranging abilities for species living on figs is supported by the sex-related differences found both in fig consumption and in foraging distances. H. monstruosus females forage at smaller distances than males (1-4 km vs. $10 \mathrm{~km}$ ), and figs make up a much smaller fraction of their diet than that of wider ranging males ( 36 vs. $58 \%$ ). One can therefore expect figs to be important only for a few "nomadic" species, as may be the case for the bulbul (Ixonotus gustatus), whose flocks increased their foraging areas during the major dry season (C. Erard, personal communication).

Do such conclusions apply to other African forests? Comparisons can be made between guenon communities of Gabon and Uganda. Cercopithecus mitis of Kibale Forest is a close relative of $C$. nictitans. Rudran (1978) found that its fruit diet included up to $21.4 \%$ figs in one month. T. Butynski (personal communication) observed that Ficus exasperata was the most frequent species eaten for one of his $C$. mitis study groups, totalling $30.8 \%$ of its food in a year. Similarly, in Kakamega Forest (Kenya), three Ficus species accounted for $17.6 \%$ of the fruit diet of $C$. mitis and for $15.9 \%$ of that of $C$. ascanius (Cords 1987). In fact, $F$. exasperata was the 19 th most common plant species in Kibale Forest and the 18th most common in Kakamega Forest, where it reached greater densities (1.6 trees/ha) than the overall density of all Makokou fig species combined. This suggests that the small role played by figs at Makokou primarily results from their poor representation at this site. On the other hand, this site offers to frugivores a much larger fruit spectrum than East African sites, due to a greater plant species richness and a greater number of trees per hectare (Gautier-Hion 1983).

But how can we explain the poor representation of figs in some tropical rain forests? Indeed, as early as 1940, Corner, dealing with forests of Malaya, wondered "why strangling figs do not occur on most big trees ... considering how vigorous they are and how easily their seeds are distributed." In the rain forest of Makokou as well as in the Taï Forest (Ivory Coast), large terrestrial figs that germinate on the ground are found mostly in secondary growth, by the forest edge, or in open forest swampy areas. Conversely, in primary mainland habitat, figs are almost exclusively hemi-epiphytic forms that germinate on trees. Their densities always remain much lower than those of both terrestrial and hemi-epiphytic figs dwelling in open habitats. For example, only 1.5 hemi-epiphytic figs/ha were found on M'passa plateau, whereas 46.5 individuals/ha were found by the forest edge along a river, a few hundred metres away. The same was true in Taï Forest, with only 4.7 hemi-epiphytic trees/ha (Michaloud and Michaloud-Pelletier 1987) vs. 51.3 terrestrial figs/ha

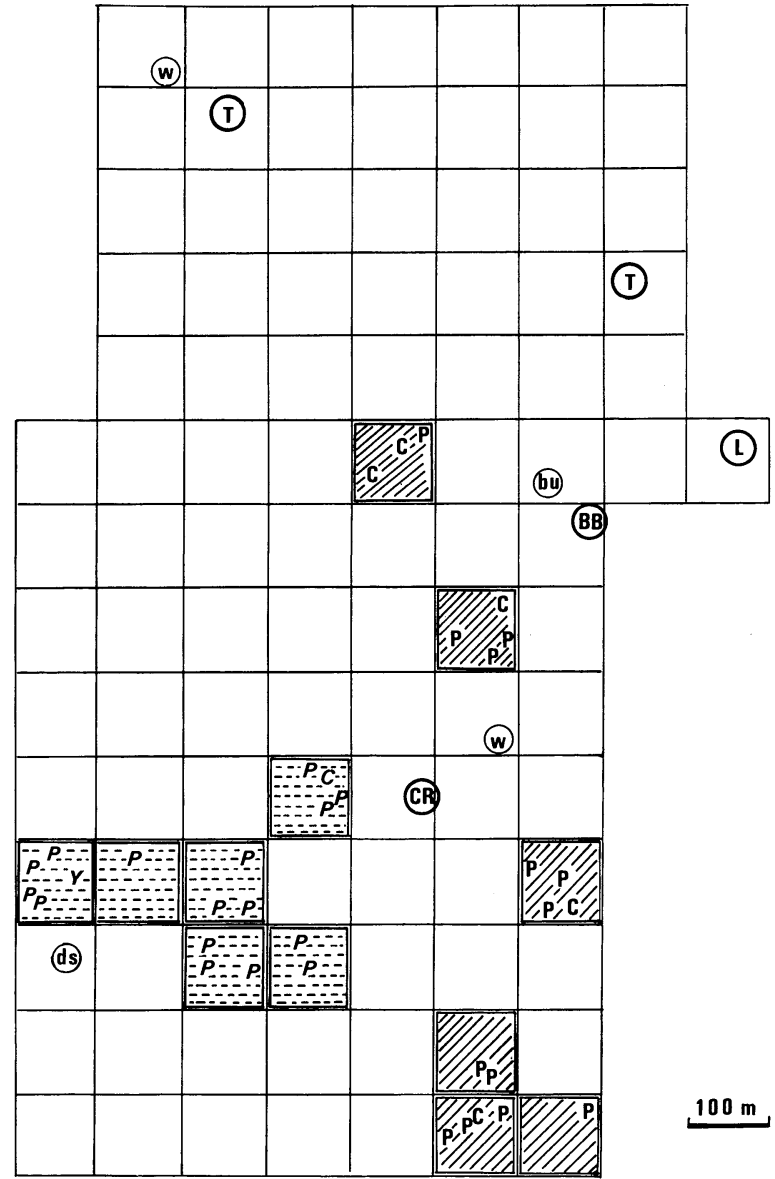

Fig. 2. Polyalthia suaveolens (P), Coelocaryon preussii (C) and Pycnanthus angolensis $(\mathrm{Y})$ trees bearing ripe fruit on a given day within six sampled hectares on the M'passa plateau (12 July 1977: hatched area; 24 August 1977: stippled area); and fruiting figs (circled letters) found from the sampling of the entire 100 ha (10 November 1980; 150 individuals monitored). $\mathrm{w}=$ Ficus wildemaniana, $\mathrm{T}=F$. toninghii, $\mathrm{L}=F$. lingua, bu $=F$. burretiana, $\mathrm{BB}=F$. bubu, $\mathrm{CR}=F$. craterostoma, $\mathrm{D}=F$. densistipulata (uppercase letters indicate ripe fruit; lowercase indicate unripe fruit).

in an open area $\sim 200 \mathrm{~km}$ away in the same region (Thomas 1982). Again, in a "typical second-growth neotropical lowland forest" of Barro Colorado, Milton et al. (1982) found only terrestrial figs; their density was "five to nine times as high as in older sections of the forest"); $83.3 \%$ of these species were Ficus yoponensis and $F$. insipida (Morrison 1978), species that are not recruited into old second-growth or primary forest, except in light gaps or along riverbanks (Milton et al. 1982).

Michaloud and Michaloud-Pelletier (1987), analyzing the structural characteristics of trees colonized by hemi-epiphytic figs in Taï Forest, suggested that access to light was the most important parameter determining successful fig settlement. Since only $20.6 \%$ of the 160 species of trees had individuals colonized by figs, the authors concluded that the low density of fig trees found 
there (4.69 trees/ha, with none of 19 species reaching 1 tree/ha) was the result of a lack of hosts offering suitable light conditions for settlement of figs. It is likely that similar explanations could apply to Makokou Forest, whose floristic composition is close to that of Taï Forest.

From these data, one can foresee that any rain forest evolving from second-growth stage to older stages (1) will not have its population of terrestrial figs renewed, (2) will have room only for hemi-epiphytic figs to settle, (3) and therefore will undergo a severe decrease in fig density and fruit production. The latter decrease results from both the decrease in density and in individual crop size. As a consequence, figs may constitute a staple food for frugivores, in a given rain forest at a given successional stage, but will no longer represent a staple food when the forest reaches the subsequent stages of maturation. However, the decrease in crop size will depend on the relative abundance of fig trees belonging to species that can grow to stranglers. It is possible that rain forests growing on highly productive soils harbor higher densities of such species than Makokou forest. In such a case, the decrease in crop size would be less important, since hemi-epiphytic stranglers can produce as big a fruit crop as terrestrial figs do (up to 40000 fruits in Barro Colorado, Hladik and Hladik 1969).

It would be useful to learn how, in a given rain forest, a community of frugivores would adapt itself to a change in availability of its staple food resources through maturation of the forest. Would the diversity of potential food species be a factor determining whether consumers could remain, feeding on substitutes, or whether they would have to move to other habitats? In the latter case, it is actually a question of a "keystone" resource, since animals have to move to search for the same food species elsewhere. In the former case, one can speak only of key resources, in so far as frugivores are able to switch their diet onto substitutes.

These considerations stress the difficulty of generalizing, not only between continents but within a single country, where forests are made up of a mosaic of different seral stages. Incidentally, this points out the need for moderating generalizations drawn from studies conducted in more or less disturbed or small-sized forests such as those in East Africa, at the extreme limit of the tropical rain forest.

\section{CONCLUSION}

In periods of low fruit availability, the frugivores of Makokou, as well as those of other tropical rain forests (e.g., the Kutai Nature Reserve in Indonesia, Leighton and Leighton 1983; and the Manu site in Peru, Terborgh 1986), rely on a few plant species characterized by high density, high rates of fruit production, and/or highly predictable fruiting periods. But these key species do not necessarily belong to the same taxonomic groups on all continents, or at every maturational stage within a single forest. At Makokou, Polyalthia suaveolens and
Myristicaceae are, at the present time, the species most suited to play this role, whereas figs are mainly food for bats. An improved knowledge of such key resources might have profound implications for the management and conservation of tropical rain forest ecosystems.

\section{ACKNOWLEDGMENTS}

Warmest thanks are due to C. Erard and P. Heckestweiler who provided us with unpublished data. For helpful comments on the manuscript, we are grateful to Professor F. Bourlière, to Drs. L. Miller, J. Bradbury, C. Janson, and to an anonymous reviewer. We thank Dr. P. Posso, Director of the CENAREST of Makokou, for facilitating our study in Gabon. The research was supported by the Centre National de la Recherche Scientifique (Laboratoire ECOTROP).

\section{LITERATURE CiTED}

Bradbury, J. W. 1977. Lek mating behavior in the hammerheaded bat. Zeitschrift für Tierpsychologie 45:225-255. 1981. The evolution of leks. Pages 138-169 in R. D. Alexander and D. Tinkle, editors. Natural selection and social behavior. Chiron, New York, New York, USA.

Brosset, A., and C. Erard. 1986. Les oiseaux des régions forestières du Nord-Est Gabon. Volume I. Ecologie et comportement des espèces. Revue d'Ecologie (la Terre et la Vie), supplément 3 .

Caballé, G. 1986. Sur la biologie des lianes ligneuses en forêt Gabonaise. Thèse de Doctorat. Université de Montpellier, Montpellier, France.

Cords, M. 1987. Mixed-species association of Cercopithecus monkeys in the Kakamega Forest, Kenya. University of California Publications in Zoology 117.

Corner, E. J. H. 1940. Strangling figs. Pages 664-665 in Wayside trees of Malaya-Singapore. The Government Printer, Singapore, Malaysia.

Dubost, G. 1984. Comparisons of the diets of frugivorous forest ruminants of Gabon. Journal of Mammalogy 65:298316.

Duplantier, J-M. 1982. Les rongeurs myomorphes forestiers du Nord Est du Gabon. Thèse de $3^{\circ}$ cycle. Université de Montpellier, Montpellier, France.

Emmons, L. 1980. Ecology and resource partitioning among nine species of African rain forest squirrels. Ecological Monographs 50:31-54.

Emmons, L., A. Gautier-Hion, and G. Dubost. 1983. Community structure of the frugivorous-folivorous forest mammals of Gabon. Journal of Zoology, London 199:209-222.

Feer, F. 1988. Stratégies écologiques chez deux ruminants forestiers sympatriques de la forêt sempervirente africaine (Cephalophus callipygus et $C$. dorsalis). Thèse de Doctorat. Université de Paris VI, Paris, France.

Gautier-Hion, A. 1971. L'écologie du talapoin du Gabon (Miopithecus talapoin). La Terre et la Vie 35:511-536.

- 1977. Données sur le régime alimentaire de Cercocebus albigena dans le Nord-Est du Gabon. La Terre et la Vie 31:579-585.

- 1 1980. Seasonal variations of diet related to species and sex in a community of Cercopithecus monkeys. Journal of Animal Ecology 49:237-269.

1983. Leaf consumption by monkeys in western and eastern Africa: a comparison. African Journal of Ecology 21:107-113.

Gautier-Hion, A., and J-P. Gautier. 1978. Le singe de Brazza: une stratégie originale. Zeitschrift für Tierpsychologie 46:84-104.

Gautier-Hion, A., L. Emmons, and G. Dubost. 1980. A comparison of the diets of three major groups of primary consumers of Gabon. Oecologia (Berlin) 45:182-189.

Gautier-Hion, A., J-P. Gautier, and R. Quris. 1981. Forest 
structure and fruit availability as complementary factors influencing habitat use by a troop of monkeys (Cercopithecus cephus). Revue d'Ecologie (la Terre et la Vie) 35:511536.

Gautier-Hion, A., J-M. Duplantier, R. Quris, F. Feer, C. Sourd, J-P. Decoux, G. Dubost, L. Emmons, C. Erard, P. Heckestweiler, A. Moungazi, C. Roussilhon, and J-M. Thiollay. 1985a. Fruit characters as a basis of fruit choice and seed dispersal in a tropical forest vertebrate community. Oecologia (Berlin) 65:324-337.

Gautier-Hion, A., J-M. Duplantier, L. Emmons, F. Feer, P. Heckestweiler, A. Moungazi, R. Quris, and C. Sourd. 1985b. Coadaptation entre rythmes de fructification et frugivorie en forêt tropicale humide du Gabon: mythe ou réalité. Revue d'Ecologie (la Terre et la Vie) 40:405-434.

Hladik, A., and C. M. Hladik. 1969. Rapports trophiques entre végétation et primates dans la forêt de Barro Colorado (Panama). La Terre et la Vie 1:25-117.

Leighton, M., and D. R. Leighton. 1983. Vertebrate responses to fruiting seasonality within a Bornean rain forest. Pages 181-196 in S. L. Sutton, T. C. Whitmore, and A. C. Chadwick, editors. Tropical rain forest: ecology and management. Blackwell Scientific, Oxford, England.

Michaloud, G. 1988. Aspects de la reproduction des figuiers monoïques en forêt équatoriale africaine. Thèse d'Université, Université des Sciences et Techniques du Languedoc, Montpellier, France.

Michaloud, G., and S. Michaloud-Pelletier. 1987. Ficus hemi- epiphytes (Moraceae) et arbres supports. Biotropica 19:125136.

Milton, K., D. M. Windsor, D. W. Morrison, and M. A. Estribi. 1982. Fruiting phenologies of two neotropical $\mathrm{Fi}$ cus species. Ecology 63:752-762.

Morrison, D. W. 1978. Foraging ecology and energetics of the frugivorous bat Artibeus jamaicensis. Ecology 59:716723.

Quris, R. 1975. Ecologie et organisation sociale de Cercocebus galeritus agilis dans le Nord-Est du Gabon. Thèse de $3^{\circ}$ cycle. Université de Rennes, Rennes, France.

Rudran, R. 1978. Socioecology of the blue monkeys (Cercopithecus mitis stuhlmanni) of the Kibale Forest, Uganda. Smithsonian Contributions to Zoology 249:1-88.

Sourd, C. 1983. Etude des modes d'exploitation des ressources fruitières par Cercopithecus cephus au cours d'un cycle annuel. Thèse de $3^{\circ}$ cycle. Université de Rennes, Rennes, France.

Sourd, C., and A. Gautier-Hion. 1986. Fruit selection by a forest guenon. Journal of Animal Ecology 55:235-244.

Terborgh, J. 1986. Keystone plant resources in the tropical forest. Pages 330-344 in M. E. Soule, editor. Conservation biology: the science of scarcity and diversity. Sinauer Associates, Sunderland, Massachusetts, USA.

Thomas, D. W. 1982. The ecology of an African savanna fruit bat community: resource partitioning and role in seed dispersal. Dissertation. University of Aberdeen, Aberdeen, Scotland. 